\title{
The Influence of Financial Markets on Countries’ Economic Life
}

\author{
Narcisa Roxana Mosteanu \\ American University in the Emirates, Dubai, UAE
}

\begin{abstract}
This working paper aims to investigate one of the most present markets in whole economic life: financial market. Even if not everyone is playing on financial market, the result of trading on this markets can be seen and felt by any participant on economic life-individuals, businesses, and government. Those which are participating and trading on financial markets influence economic and social life in a way or another. The paper comes to showing how existence and trading on financial markets can change the money supply and behavior of individuals, businesses, and later they can affect entire economic and social life. The author uses financial data provided by international database such as: Eurostat, central banks, International Monetary Fund, World Bank, BMI Research, website of domestic ministries of finance, and/or economy. The research concluded that in those countries where there is an active and experienced financial market, with a huge volume of transactions, also exists a financial and fiscal stability. Unemployment rate is lower, and a higher level of confidence of investors. A very active financial market can also help governments to maintain their balance of payment in equilibrium and/or to accelerate the development of productive capacity, and for raising and maintaining social stability level.
\end{abstract}

Keywords: financial market, financial institution, financial services, capital movements, international business, macro economy

\section{Introduction and the Importance of the Theme}

Nowadays it hears more about the financial market, the stock market, about stocks and bonds, on domestic and international level. More and more people and businessmen, also including governments want to increase their revenue by investing in stocks and bonds on short or long term. Even more, the youth of today are interested in increasing their revenues by buying and selling shares on financial market.

The financial market is a marketplace where buyers and sellers participate in the trade of assets such as equities, bonds, currencies, and derivatives ${ }^{1}$. Financial markets are typically defined by having transparent pricing, basic regulations on trading, costs and fees and market forces determining the prices of securities that trade.

At this moment, financial markets can be easily found in almost every country, at different stage and volume of transactions. In some countries financial markets are still in a developing process, but in other countries, like United States of America, where New York Stock Exchange and Forex markets are located, trillions of dollars are trading on a daily basis.

Narcisa Roxana Mosteanu, Ph.D., associate professor, American University in the Emirates, College of Business Administration, Academic City, Dubai, United Arab Emirates.

Correspondence concerning this article should be addressed to Narcisa Roxana Mosteanu, American University in the Emirates, College of Business Administration, Academic City, PO Box 503000, Dubai, United Arab Emirates.

${ }^{1}$ Eugene, F., Brigham, Joel, F., Houston. (2016). Fundamental of Financial Management, South-Western College Pub. 
Financial markets make the value of money and prices of most financial instruments which are tradeable. If the economy is going well and the demand is higher, prices may rise above historical levels, and the earnings are higher. However, the macroeconomic forces as changing in levels of taxes, decreasing in national production or level of employment may lead to a reduction of prices of tradeable instruments, which can lead to a reduction in investors' earnings.

The research paper aims to investigate if the financial market plays a role in the economic and social life of a country, and how. At the beginning, the author starts to present what financial market is, a short history of its appearance, and how it works in the present time. Later on, the author using the database provided by public domestic and international well known authorities, starts to analyze the main financial indicators which indicate the wealth and the level of an economic and social life of a country. The research concluded that the existence of a strong financial market can lead to an entire economic and social development of a country.

\section{Literature Review}

The research started with the history of financial markets. For this, the analysis looked back into the history and tried to find out from old materials, articles, books, and data related to what makes this kind of market to be part of economic life. Later on the statistical data offered by public website from the most important financial markets in the world, and public financial institutions will be used in order to show with figures their influence on money movement, on business and why not, on country economic and social level.

\section{The History of Financial Markets}

Intensifying of international economic exchanges of good, services, and the need for capital to support the development of trade led to the emergence of financial markets, especially capital markets and later on to foreign exchange markets ${ }^{2}$.

The research reveals that the first type of financial market starts in Europe. Just like in any corner of the world, there were always people who had financial resources and others who were looking for such resources. Private lenders in Europe filled important gaps left by large banks. In this time, appeared intermediaries which were trying to cover the debts of the business. In the 1300s, the Venetians (Italy) have been leaders in the field and started their first trading securities in the country and between countries. Later on, Belgium boasts Stock Exchange since 1531. In 1531 took place the first meeting between brokers and lenders to deal with business, government, and even individual debt issues.

The first stock exchange in London was created in 1773. British East India Company was one of the greatest competitive advantages firm in financial history-a government-backed monopoly. Some investors began to receive dividends and to sell shares for huge fortunes, other investors were hungry for a piece of the action. Budding financial boom in England came so quickly for this reason that there were created first rules and regulations for the issuance of shares. Sooner the companies start to issue shares for things which were not quite real. Therefore, later on, the bubble bursts when the specialized companies failed to pay any dividends off its meager profits, highlighting the difference between these new share issues and the British East India Company. The subsequent crash caused the government to outlaw the issuing of shares - the ban held until 1825 .

\footnotetext{
2 Jeff Madura. (2016). International Financial Management, 13th ed, Thomson South Western, USA.
} 
In 1792, the New York Stock Exchange was officially created in New York ${ }^{3}$. Since the London Stock Exchange was handcuffed by the law that restricts, New York Stock Exchange was occupied by trade stocks, since its inception. NYSE was not the first stock exchange in the US, however, that honor goes to Philadelphia Stock Exchange, but quickly became the most powerful. Founded by brokers, New York Stock Exchange made its home on Wall Street. Location parts, more than anything else, led to the dominance that NYSE rapidly reached. It was in the heart of all business and commerce coming to and going from the United States, as well as internal basis for most banks and major corporations. By setting demanding printing needs and errands, New York Stock Exchange became a very wealthy institution.

At international level, London Stock Exchange acts as a major exchange for Europe, but the biggest corporations that were able to list internationally still listed in New York Stock Exchange.

Nowadays, many developed countries as Switzerland, Germany, France, Japan, Australia, Canada, United Arab Emirates, and Saudi Arabia created their own stock exchange, but these were largely seen as proving grounds for domestic companies to inhabit until they were ready to make the leap to the London Stock Exchange and from there to the big leagues of the New York Stock Exchange.

\section{Financial Markets Nowadays}

Contemporary economists argue that financial market development is a process which is also supported by the international financial institutions in order to reduce the dependence on external financing and banking sector, and thus because the cost of financing in the capital market is much lower than institutional funding (Andrei Radulescu—Capital Market Journal Interview) ${ }^{4}$. Our research noted that countries where developed financial markets exist - through which billions of dollars are traded and/or other international currencies such as British English, Euro, and Japanese yen - show a developed economic and social level, sustained economic growth, and a low country risk.

The research shows that in the present time the biggest financial markets in the world are located in the most developed countries such as: USA (New York Stock Exchange and NASDAQ — both in New York), United Kingdom (London Stock Exchange Group-London), Japan (Japan Exchange Group-Tokyo), and China (Shanghai Stock Exchange). Table 1 presents the first 10 biggest financial markets in the world, according to the trade monthly volume. Financial markets participate actively to the economic and social countries level development. In USA, the share of public and private business which is financed through financial market is much higher compared with other countries from Asia and Europe.

Countries with emergent economies evaluated themselves through inputs of capital from developed countries. When the development process started in countries under development economies, they become dependent on foreign financing. Therefore, in this article, it is noticed that it is imperative to implement financial market instruments in emerging countries and developing financial education. Emergent countries with an economy under development need to understand the role of the financial market in economic and social development: a mechanism that meets supply and demand of money. Basically, it is the role of financial market to ensure effective distribution of resources between those who have capital and those who need them.

\footnotetext{
${ }^{3}$ Philadelphia Stock Exchange (PHLX), now known as NASDAQ OMX PHLX, is the oldest stock exchange in the United States, founded in 1790. It is now owned by The NASDAQ OMX Group. Source: ${ }_{4}$ ttps://en.wikipedia.org/wiki/Philadelphia_Stock_Exchange. $\mathrm{http} / / /$ capital.market.md/ro/content/andrei-radulescu-dezvoltarea-pietei-de-capital-poate-dinamiza-economia-moldovei.
} 
Table 1

Major Stock Exchanges (Top 20 by Market Capitalization) of Issued Shares of Domestic Companies, as of 31 January 2015 (Monthly Reports, World Federation of Exchanges)

\begin{tabular}{|c|c|c|c|c|c|c|}
\hline Rank & Exchange & Economy & Headquarters & $\begin{array}{l}\text { Market cap } \\
\text { (USD bn) }\end{array}$ & $\begin{array}{l}\text { Monthly trade } \\
\text { volume } \\
\text { (USD bn) }\end{array}$ & $\Delta$ \\
\hline 1 & New York stock exchange & United States & New York & 19,223 & 1,520 & -5 \\
\hline 2 & NASDAQ & 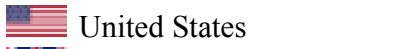 & New York & 6,831 & 1,183 & -5 \\
\hline 3 & London stock exchange group & $\begin{array}{l}\text { United Kingdom } \\
\text { Italy }\end{array}$ & London & 6,187 & 165 & +0 \\
\hline 4 & Japan exchange group-Tokyo & Japan & Tokyo & 4,485 & 402 & +9 \\
\hline 5 & Shanghai stock exchange & China & Shanghai & 3,986 & 1,278 & +8 \\
\hline 5 & Dubai financial market & $\begin{array}{l}\text { United Arab } \\
\text { Emirates }\end{array}$ & Dubai & $\mathrm{xx}$ & $3,392.90$ & -0.91 \\
\hline 6 & Hong Kong stock exchange & th Hong Kong & $\begin{array}{l}\text { Hong Kong } \\
\text { Amsterdam } \\
\text { Brussels }\end{array}$ & 3,325 & 155 & +8 \\
\hline 7 & Euronext & European Union & $\begin{array}{l}\text { Lisbon } \\
\text { London } \\
\text { Paris }\end{array}$ & 3,321 & 184 & +1 \\
\hline 8 & Shenzhen stock exchange & China & Shenzhen & 2,285 & 800 & +8 \\
\hline 9 & TMX group & Canada & Toronto & 1,939 & 120 & -5 \\
\hline 10 & Deutsche Börse & Germany & Frankfurt & 1,762 & 142 & +1 \\
\hline 11 & Bombay stock exchange & India & Mumbai & 1,682 & 11.8 & +5.5 \\
\hline 12 & National stock exchange of India & India & Mumbai & 1,642 & 62.2 & +5.5 \\
\hline 13 & SIX Swiss exchange & \$ Switzerland & Zurich & 1,516 & 126 & +1 \\
\hline 14 & Australian securities exchange & Australia & Sydney & 1,272 & 55.8 & +10 \\
\hline 15 & Korea exchange & : South Korea & Seoul & 1,251 & 136 & +9 \\
\hline 16 & OMX Nordic exchange & Northern Europe, Armenia & Stockholm & 1,212 & 63.2 & various \\
\hline 17 & JSE limited & $\geqslant$ South Africa & Johannesburg & 951 & 27.6 & +2 \\
\hline 18 & BME Spanish exchanges & Spain & Madrid & 942 & 94.0 & +1 \\
\hline 19 & Taiwan stock exchange & Taiwan & Taipei & 861 & 54.3 & +8 \\
\hline 20 & BM\&F Bovespa & Brazil & São Paulo & 824 & 51.1 & -3 \\
\hline$\ldots$ & Saudi stock exchange (Tadawul) & $=$ Saudi Arabia & Riyadh & $\ldots$ & 21.32 & +4 \\
\hline
\end{tabular}

Source: https://en.wikipedia.org/wiki/List_of_stock_exchanges; https://en.wikipedia.org/wiki/Tadawul.

Note. " $\Delta$ " to UTC, as well as "Open (UTC)" and "Close (UTC)" columns contains valid data only for standard time in a given time zone. During daylight saving time period, the UTC times will be one hour less and $\Delta$ s one hour more.

\section{Institutions and Financial Instruments}

It is understandable that financial markets play a very important role in any country economic life. Before starting to show this importance through economic indicators' eyes, it is necessary to briefly present the most known financial institutions and instruments which are present on financial markets.

Financial intermediaries act like a middle man between those who have capital in surplus and those who need funds in order to develop their business or sometimes just to multiply their money. Financial intermediaries who are active on financial markets usually are: banks (commercial or investments), insurance companies, credit unions, mutual funds, private or public pension funds, governmental agencies, central banks, financial advisors, brokerage companies, and dealers. Basically, any kind of financial institutions can deal with financial instruments, buying and selling stock and bonds, gold, international currencies, oil, or any other goods 
or services which have economic value. However, the most traded financial instruments are: stock, bonds, treasury bills or notes, international currencies, gold, silver, and oil and any other derivatives. It can be easily observing that a financial market is a broad term describing any marketplace where buyers and sellers participate in the trade of assets such as equities, bonds, currencies, and derivatives. Financial markets are typically defined by having transparent pricing, basic regulations on trading, costs and fees, and market forces determining the prices of securities that trade. Nowadays, financial markets can be found in nearly every nation in the world. Some are very small, with only a few participants, while others-like the New York Stock Exchange (NYSE) trade trillions of dollars daily ${ }^{5}$. Investors and governmental agencies had access to a large number of financial markets and exchanges representing a vast array of financial products. Some of these markets have always been open to private investors; others remained the exclusive domain of major international banks and financial professionals until the very end of the twentieth century. Therefore, the most important thing is that all these financial markets through their financial intermediation play a very important role in every country life by helping them to develop themselves.

From the literature it is very easy to notice that on financial markets a high volume of money is traded using securities and other commodities. However, what the paper is coming to present is how this large volume of trading affecting unemployment rate and the confidence of investors can change the vision about stability of financial and fiscal system of a country.

\section{Indicators Used in the Research and Analysis Result}

In order to investigate the influence of financial markets on countries economic life, it was chosen some important indicators. Based on the available data and on what it was the purpose of the investigation, it was also indicated to take into consideration of lagging indicators (which reflect the economy's historical performance and changes to these are only identifiable after an economic trend or pattern has already been established) and leading indicators (which often change prior to large economic adjustments and, as such, can be used to predict future trends). The research used database such as: Eurostat, central banks, International Monetary Fund, World Bank, BMI Research, website of domestic ministries of finance, and/or economy. The research took into consideration of countries from all over the world, developed, or with their economy under development process. Thus because, it wanted to proof that financial markets help economies, investments, and economic growth. Therefore, there were created three categories: countries with a strong financial market activity (United States, United Kingdom, Germany, and France) using conventional finance system; countries with a strong financial market activity (United Arab Emirates and Saudi Arabia) using Islamic finance system; and emergent countries where financial markets are at an incipient level (Bulgaria, Czech Republic, Greece, Hungary, Italy, Poland, Romania, and Spain).

\section{The Interdependence Between Investments and Economic Growth}

In the first part of this paper, it has been noticed that the biggest financial markets in the world are located in the most developed countries. Figures 1-5 showed the proportion of foreign investments in gross domestic product and the economic growth.

The research concluded that in those countries where there is an active financial market and with an old tradition in the field, the outward foreign direct investment volume is high (the case of countries United

\footnotetext{
${ }^{5} \mathrm{http} / /$ www.investopedia.com/walkthrough/corporate-finance/1/financial-markets.aspx.
} 
Kingdom, United States, France, and Germany). The analysis presented, on one hand that, the volume of investments is an increasing trend in recent years also in countries where it is an active young financial market (such as Saudi Arabia and the United Arab Emirates). On the other hand, in countries where financial markets are underdeveloped or quite young, both international and domestic level, the volume of direct investments is low.

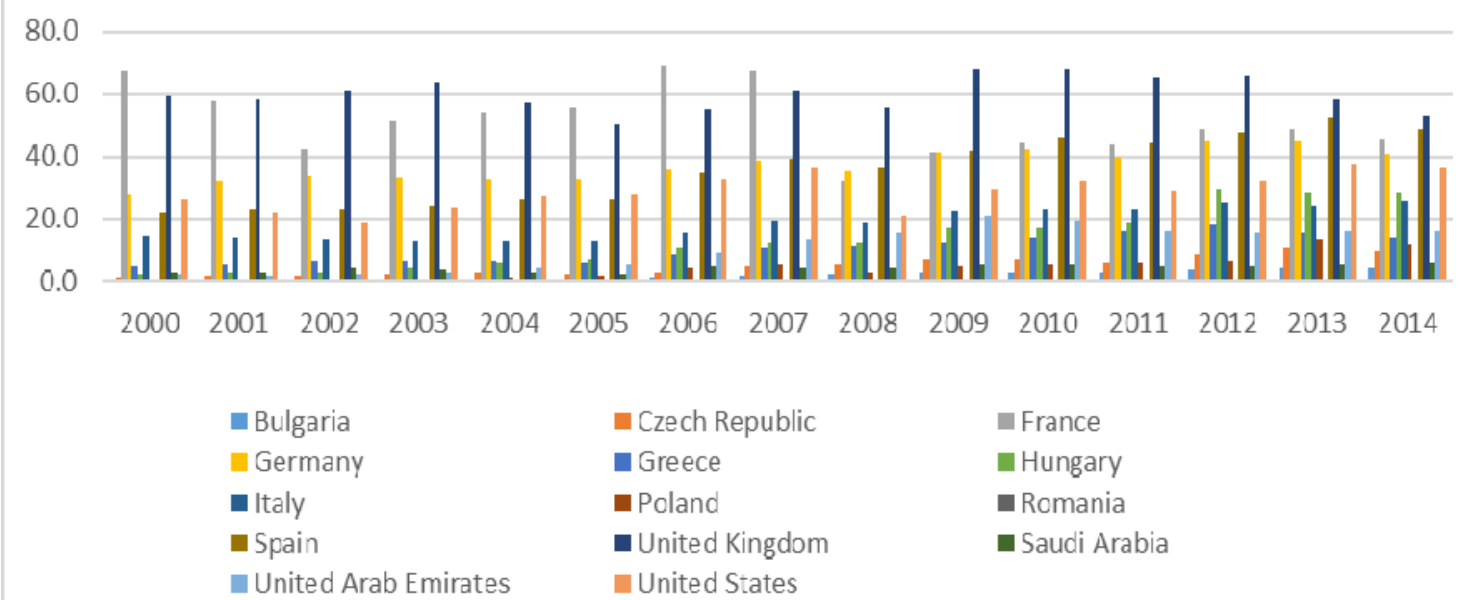

Figure 1. Foreign direct investment: outward FDI stock, \% in GDP. Source: based on BMI Research data base, on 30th of June 2016, https://bmo.bmiresearch.com.

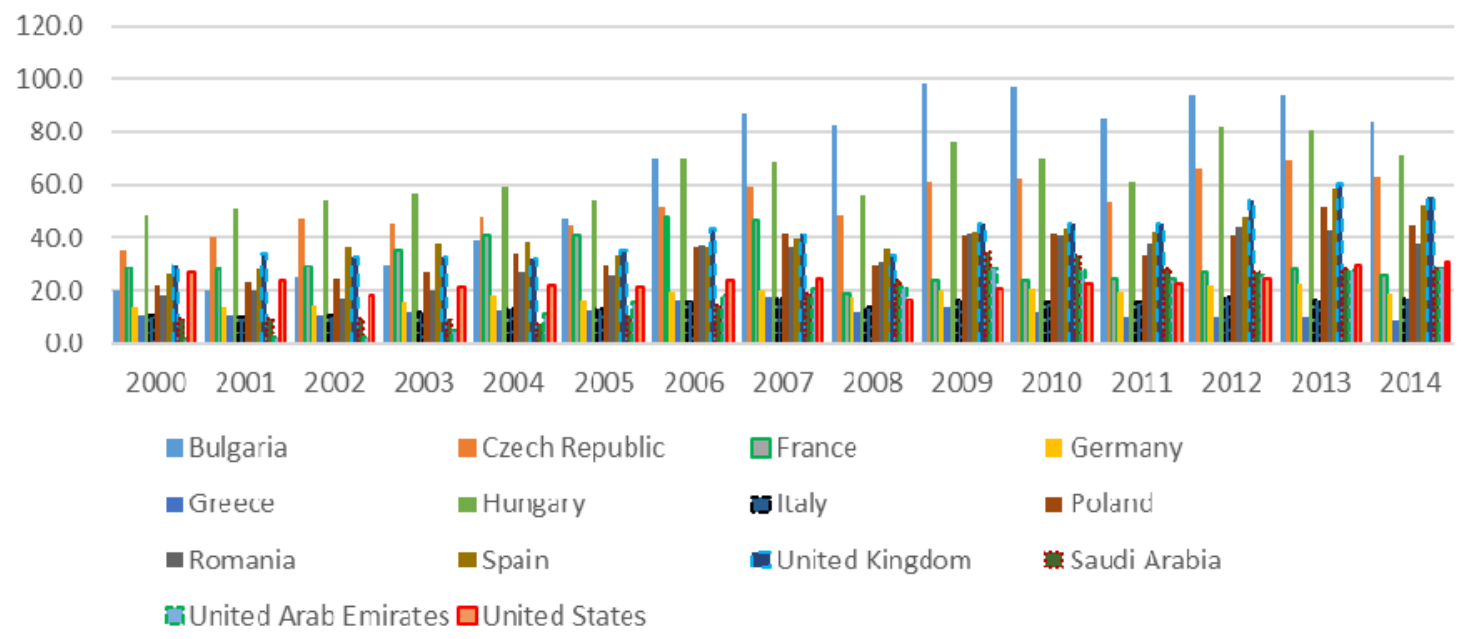

Figure 2. Foreign direct investment: inward FDI stock, \% in GDP. Source: based on BMI Research data base, on 30th of June 2016, https://bmo.bmiresearch.com.

In terms of inward foreign direct investments, it can be seen that the most investments made in recent years, were carried out in emergent countries where financial markets are underdevelopment but where there is a potential for economic development. It is case of Bulgaria, Hungary, Poland, and Spain.

Relating portfolio investments, it can say that it represents mainly stock and bond market investments.

In terms of portfolio investment inflows, which refer to the flow of debt security and equity investments by non-residents into the economy, it can say that the greatest investments are made in the USA, where indeed there is the largest financial market in the world, NYSE. 


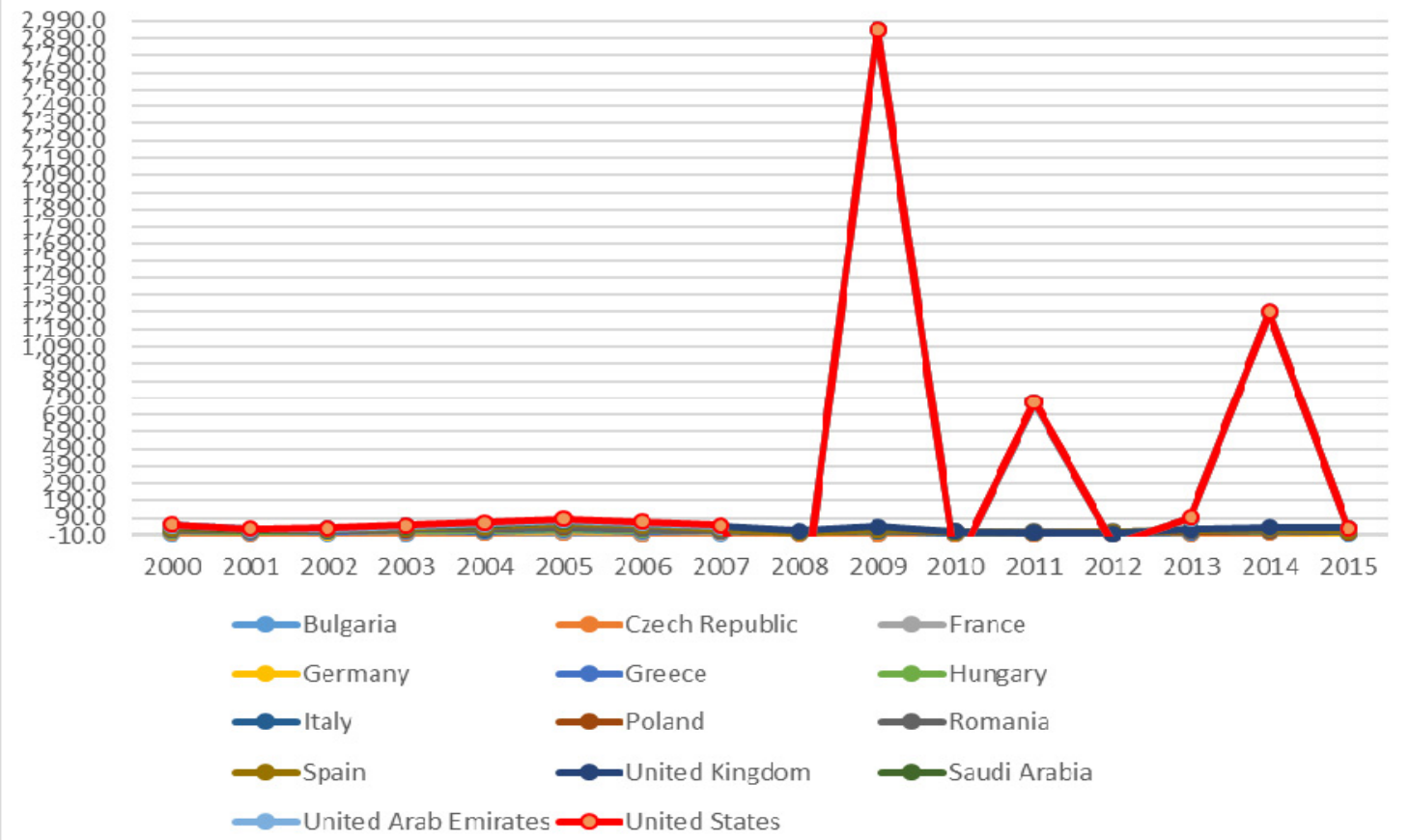

Figure 3. Portfolio investment inflows, \% of GDP. Source: based on BMI Research data base, on 30th of June 2016, https://bmo.bmiresearch.com, Bulgarian National Bank, Czech national Bank, Banque de France, Bundesbank, National Bank of Hungary, National Bank of Poland, Banco de España, Saudi Arabian Monetary Agency (SAMA), UAE Central Bank, Bureau of Economic Analysis US, Eurostat.
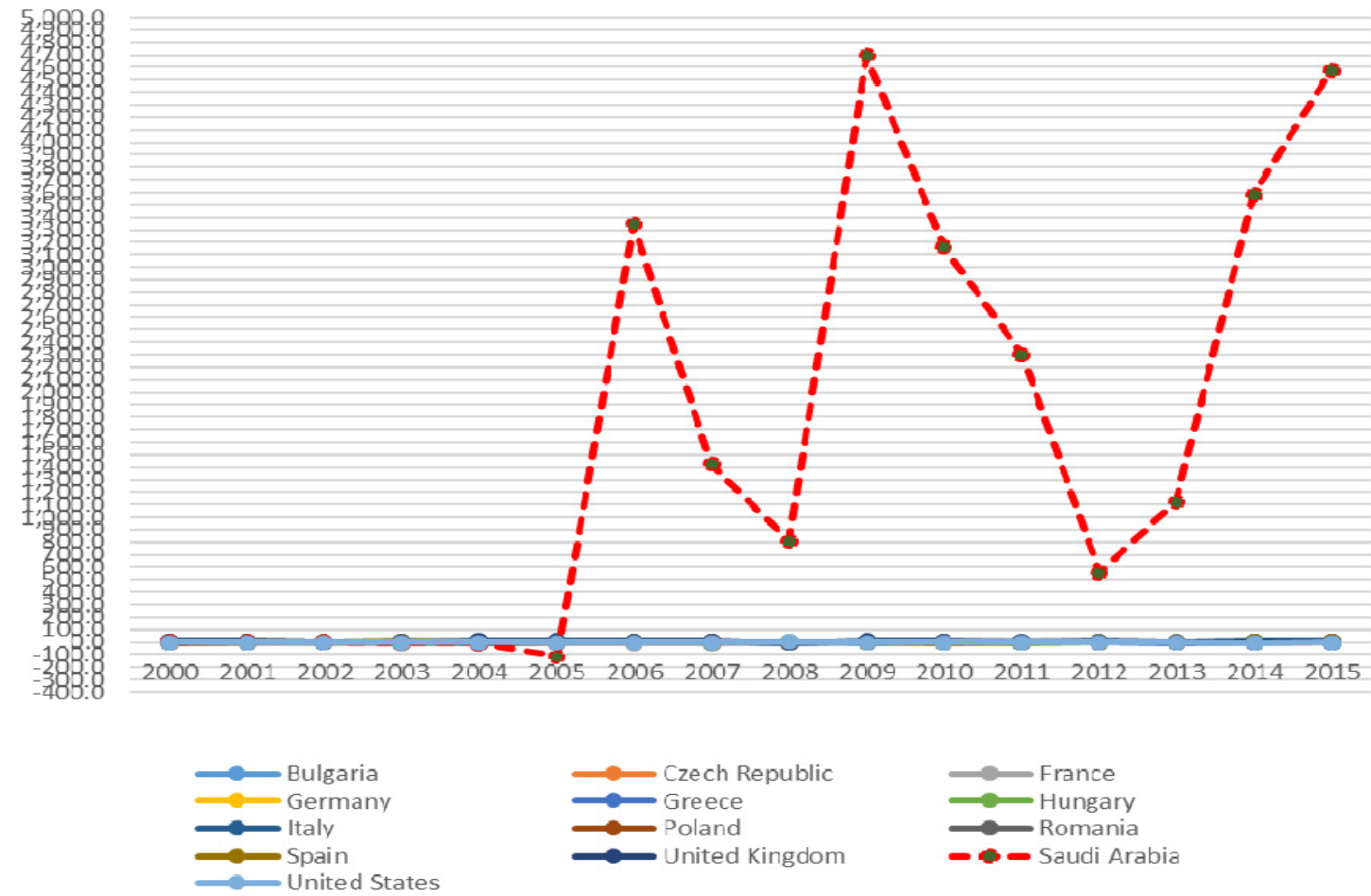

Figure 4. Portfolio investment outflows, \% of GDP. Source: based on BMI Research data base, on 30th of June 2016, https://bmo.bmiresearch.com, Bulgarian National Bank, Czech national Bank, Banque de France, Bundesbank, National Bank of Hungary, National Bank of Poland, Banco de España, Saudi Arabian Monetary Agency (SAMA), Bureau of Economic Analysis US, Eurostat. 
In countries where financial markets are not as developed, the negative inflows came from foreign investors which are removing money from countries where investment was made (case of emerging economies).

Regarding portfolio investment outflows which refer to the flow of debt security and equity investments by residents abroad, it can easily observe that most of the countries register a lower level or a quite a negative one. The negative outflows are coming from investors which are repatriating funds or from investors which are removing money from their countries (particularly in emerging countries). The exception is Saudi Arabia, where are the new financial market opened in 2005, comes with an increase in investment portfolio.
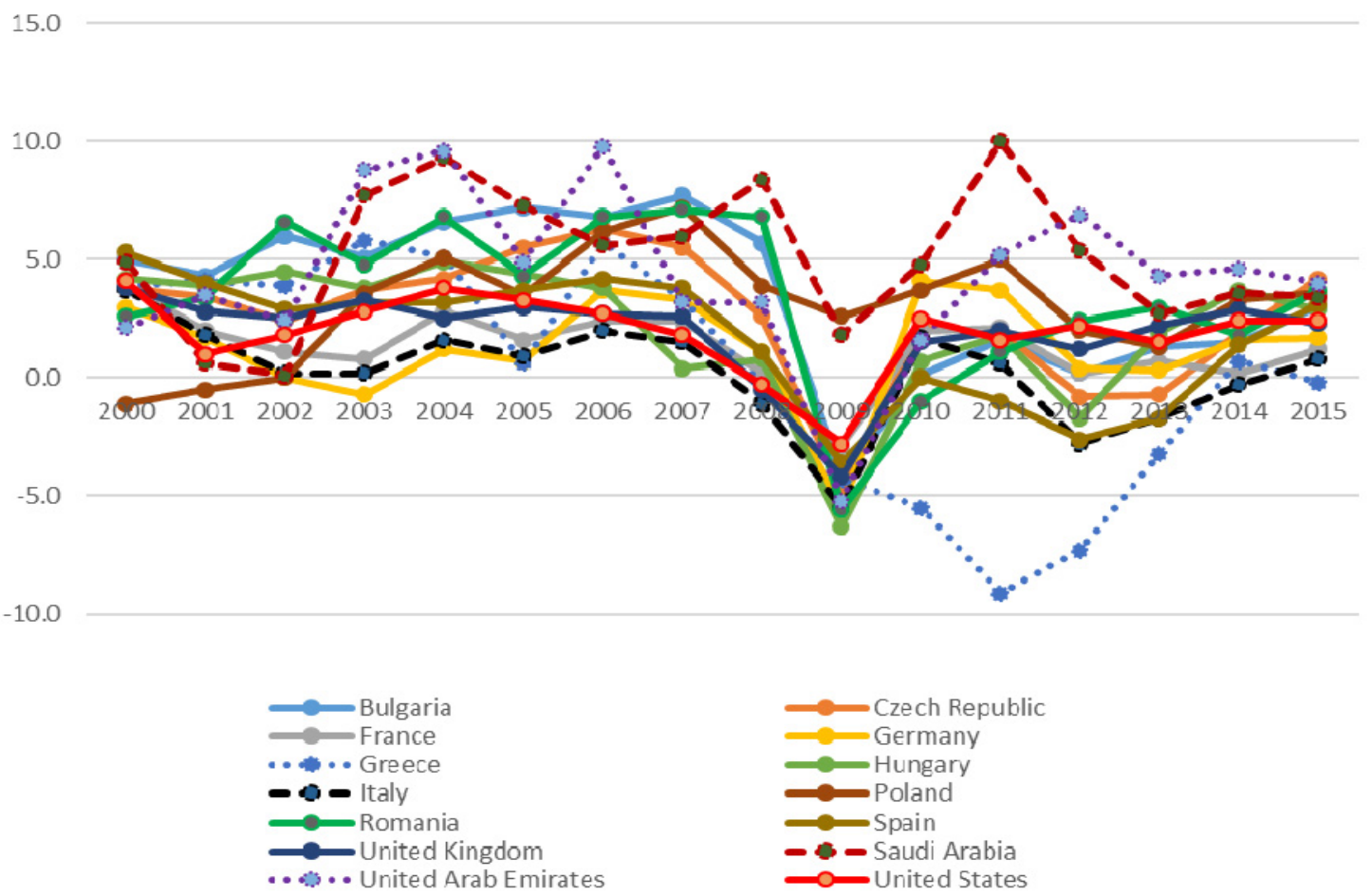

Figure 5. Real GDP growth, \% y-o-y. Source: based on BMI Research data base, on 30th of June 2016, https://bmo.bmiresearch.com, UAE National Bureau of Statistics, Eurostat, Saudi Arabian Monetary Agency (SAMA), Bureau of Economic Analysis US.

There is a direct link between financial markets and economic growth. Financial market facilitates the transfer of capital from investors who have surplus money to those who need capital to cover their expenses or to develop their business. Usually, this transfer takes place through direct and indirect investments. Investments through financial capital infusion, lead to increase of production, increase of consumption, increase of income at private, and public sector (increasing production, sales, it leads to increasing the volume of taxes and other taxes payable to the state's budget). All of this is focused on economic growth.

Analysis undertaken noticed that in those countries where financial market exists, volume of investments increases and facilitates increased production, consumption, income, and participation in the balance of payments equilibrium. For those countries taken into analysis, it can be seen from Figure 5 that countries with a strong tradition of the financial market, register massive investments and also their economic level records an economic growth. 


\section{The Interdependence Between Investments and Unemployment Rate}

As previously presented during this paper, financial markets facilitate capital transfers from those who have surplus to those in need. In the first phase, the transfer of capital benefits both sides. Investors want to multiply and to give value to their surplus of money, and individuals and businessmen want to cover expenses and make profit. In the second phase, it can easily see how investments' growth, production' growth lead to increasing the number of jobs thus reduce unemployment.
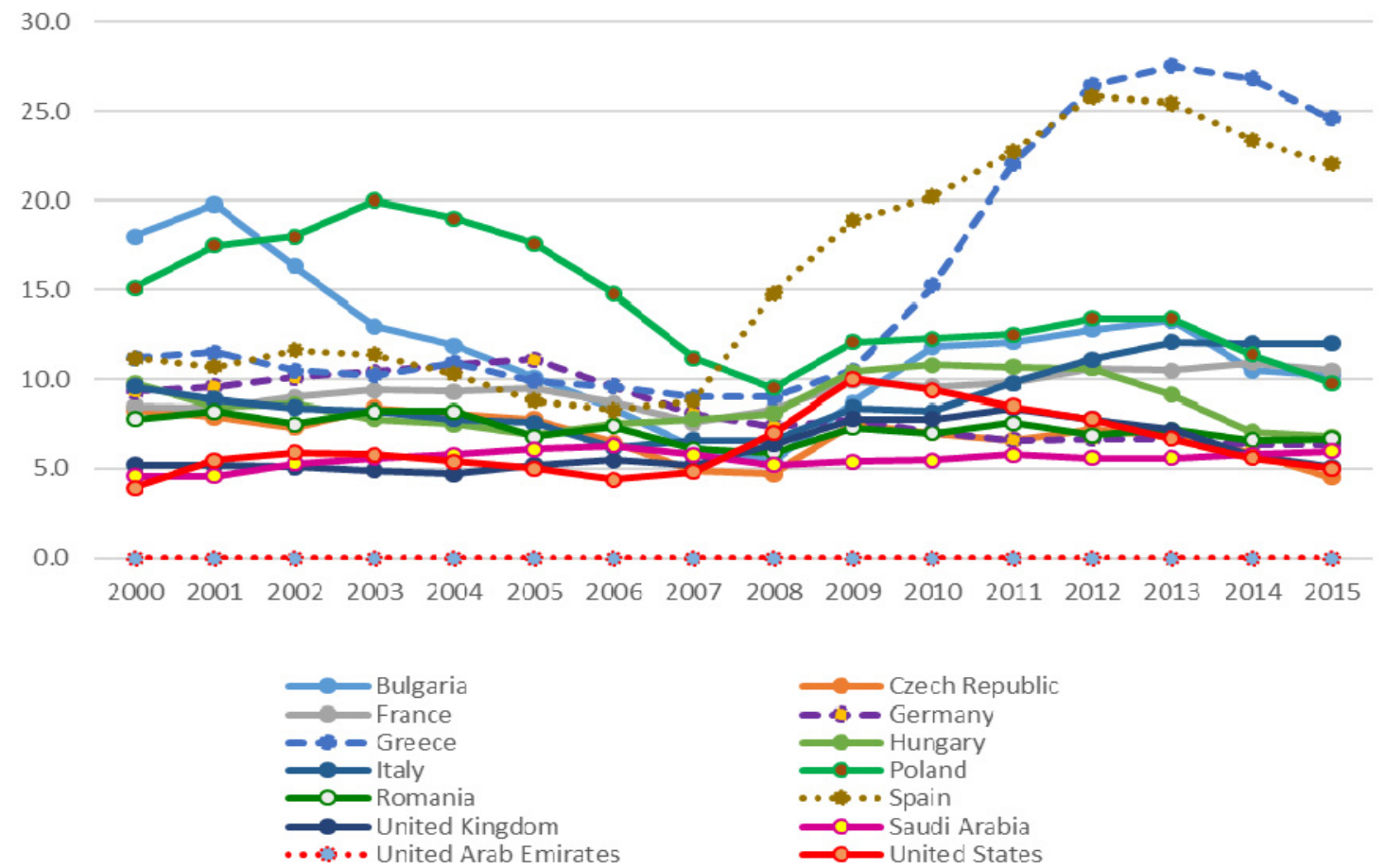

Figure 6. Unemployment, \% of labour force. Source: based on BMI Research data base, on 30th of June 2016, https://bmo.bmiresearch.com, Bulgarian National Bank, Czech national Bank, Banque de France, Bundesbank, National Bank of Hungary, National Bank of Poland, Banco de España, Saudi Arabian Monetary Agency (SAMA),

Bureau of Economic Analysis US, Eurostat.

The analysis conducted and correlated data related to foreign investments outlined above, it can see that countries where exist a developed financial market and large investment, then the unemployment rate is low (USA, Saudi Arabia, and Germany). Countries where there is political stability but not so developed a financial market, also recorded an unemployment low rate (Romania and Hungary), as shown in Figure 6. It is very suggestive. Exceptions include United Arab Emirates, where according to the labor law in force there is not allowed to be unemployment.

\section{Investments, Stability of Financial Markets, and Countries Risks}

In terms of country risk, it can see that in those countries where there are developed financial markets, the investment risk is very low. Figure 7 shows the evolution of country risk during the period 2007-2016, the percentage is far higher, the better subsided country risk. Thus, in countries such as USA and United Kingdom, country risk is very low, and this is because there is stability both for financial and fiscal law and for political environment. Legislative and political stability made the existence and development of financial markets possible, and investors started to have confidence in making investments in such countries. In contrast, in 
countries like Greece or Bulgaria, the country risk is very high, due to the instability of financial and tax legislation as well as the unstable political situation. This instability has made foreign investments and financial market harder to be developed, as well as the economy of these countries.

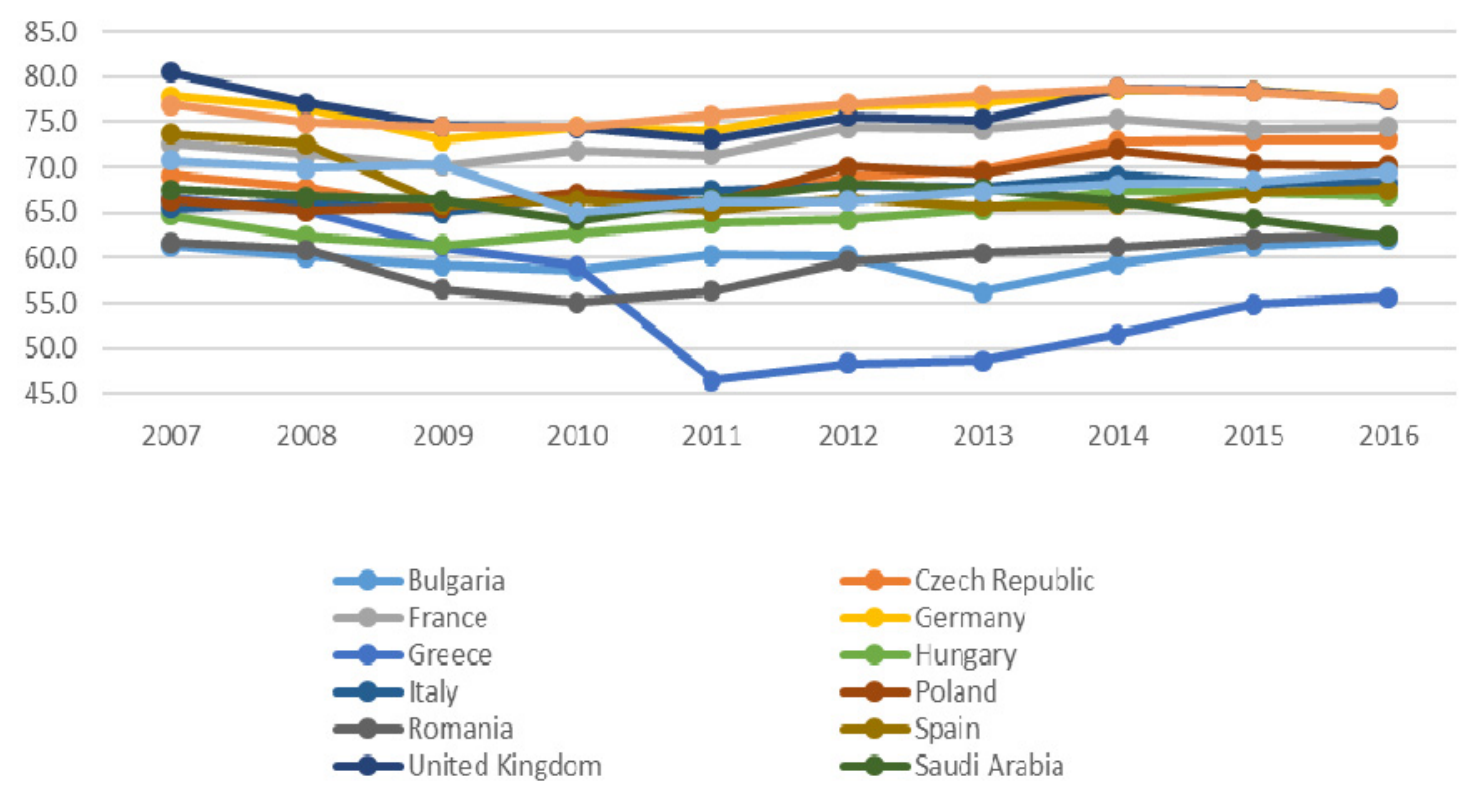

Figure 7. Country risk index. Source: based on BMI Research data base, on 30th of June 2016, https://bmo.bmiresearch.com, UAE National Bureau of Statistics, Eurostat, Saudi Arabian Monetary Agency (SAMA), Bureau of Economic Analysis US.

Note. The composite index (Country Risk Index) is a weighted average of the short-term political and economic index and long-term political and economic index. This allows a ranking of all countries in our emerging markets and developed countries universe. Score is $\%$ of 100.100 being best, 0 worst.

\section{Financial Markets, Monetary Policy, and Fiscal Policy}

Regarding the interdependence between the existence of a stable and balanced monetary policy and proper functioning of financial markets, analysis concluded showed that, as in the above, this interdependence is tied.

Therefore, in countries where there is a monetary policy based on controlled inflation, stability of foreign exchange rate, stable and a lower level of the rate of credit, access to loans and capital market, financial market develops, allowing access investments both internally and internationally.

Figure 8 presents risk on monetary policy in the period 2000-2016. It can be seen that in those countries where the currency is balanced, there also exist developed financial markets (such as in the USA and United Kingdom). In countries with unstable monetary policy the financial markets are not developed (the case of Greece, Bulgaria, and Czech Republic).

Balance of payments summarizes a country's economic transactions with the rest of the world. Balance of payments presents the balance of a country' international payment and its international investment position. Balance of payments reflects an economy's health. A country where financial market is developed, and where there is a flux of investment, is present a healthy economy.

Taking a view on the Figure 9, it can see that those countries where the flux of investments is higher, and the financial market is developed, present a good balance of payment. Again developed countries record a lower risk. 


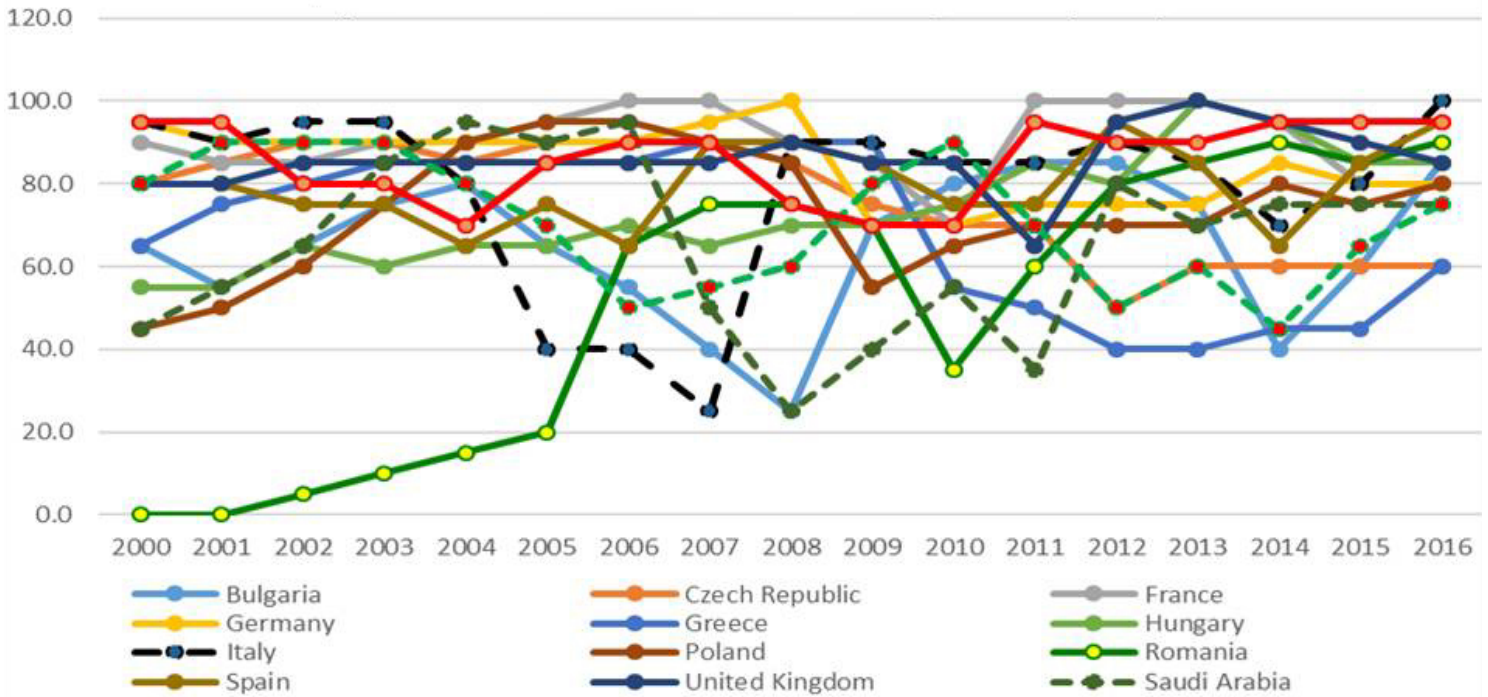

Figure 8. Short term economic risk index, monetary policy. Source: based on BMI Research data base, on 30th of June 2016, https://bmo.bmiresearch.com, UAE National Bureau of Statistics, Eurostat, Saudi Arabian Monetary Agency (SAMA), Bureau of Economic Analysis US.

Note. The Short Term Economic Risk Index, Monetary Policy is a component of the short-term economic risk index. Reflects inflation and real interest rates. Score is \% of 100.100 being best, 0 worst.

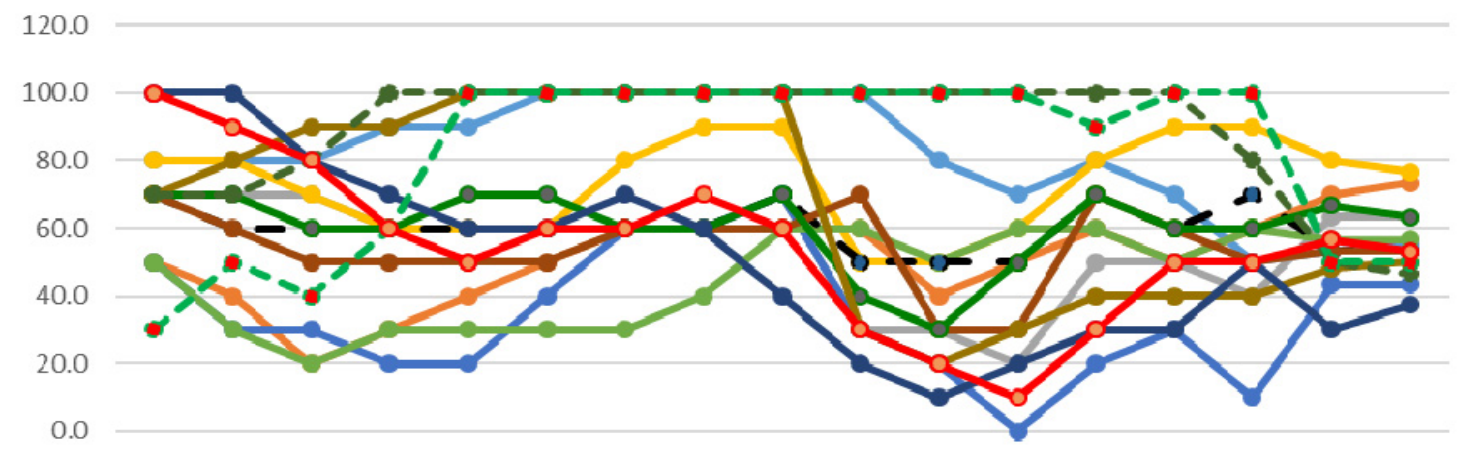

20002001200220032004200520062007200820092010201120122013201420152016
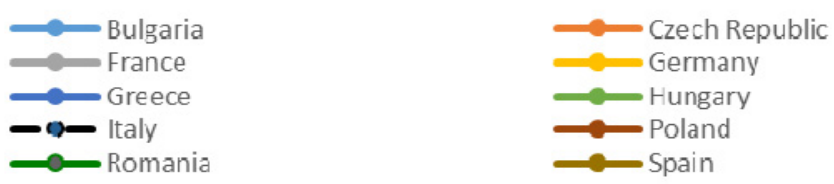

Figure 9. Short term economic risk index, fiscal policy. Source: based on BMI Research data base, on 30th of June 2016, https://bmo.bmiresearch.com, UAE National Bureau of Statistics, Eurostat, Saudi Arabian Monetary Agency (SAMA), Bureau of Economic Analysis US.

Note. The Short Term Economic Risk Index, Fiscal Policy is a component of the short-term economic risk index. Reflects fiscal balance as a \% of GDP and government debt as a \% of GDP. Score is \% of 100.100 being best, 0 worst.

\section{The Interdependence Between Financial Markets and Social Stability}

There is an interdependence between financial markets and social stability in both ways. Financial market cannot be developed if there is no confident that investments are safe in one specific country. Investments 
become safe if fiscal, financial, and monetary policies are stable and conducted in order to develop economic and social level, which means social and economic stability. If there is stability in economics policies area, there is no public unrest, and investors become confident in their business, unemployment rate becomes lower, and all economic level increases.

Looking back to all countries subject of the analysis, it can notice that those countries where exist a higher social stability risk (as Greece, Spain, and Bulgaria) financial markets are underdevelopment, and also register (as we present above) a low level of economic growth. And again countries where exist a lower risk of social stability (USA, United Kingdom, United Arab Emirates, and Germany) have the biggest financial markets in the world.

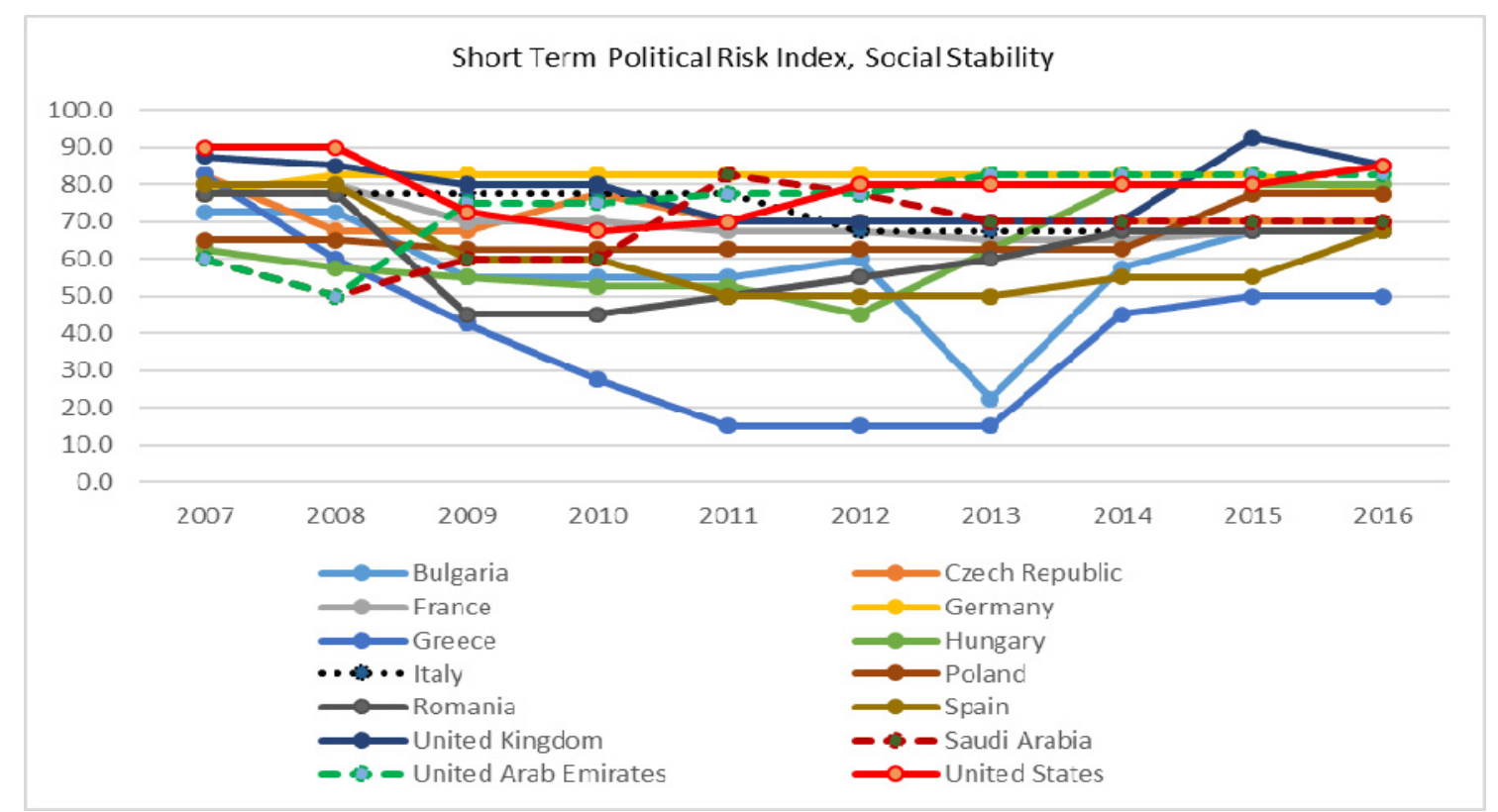

Figure 10. Short term political risk index, social stability. Source: based on BMI research data base, on 30th of June 2016, https://bmo.bmiresearch.com, UAE National Bureau of Statistics, Eurostat, Saudi Arabian Monetary Agency (SAMA), Bureau of Economic Analysis US.

Note: The Short Term Political Risk Index, Social Stability is a component of the short-term political risk index. Reflects unemployment, inflation and public unrest. Score is \% of 100.100 being best, 0 worst.

\section{Conclusions}

Capital flows, financial instruments, and operating systems are very complex nowadays, quality of intermediation, financial supervision, and players of this sophisticated game, all are put into practice to support the development of the real economy and the benefit of financial market participants.

In recent decades, financial markets have become referees and judges of the national and global economies. In fact, nothing escapes the attention of these markets: domestic macroeconomic performance reflects on the money market; governmental economic policies (fiscal, financial, monetary, and social) are assessed on stock and bond exchange markets, and the performances of state and private companies are often judged on financial markets by trading stocks and bonds.

Analysis conducted highlighted that the existence and proper functioning of financial markets facilitate social and economic development and lead to higher level of confidence of investors, and a higher prestige 
compared to other countries. Businessmen can rely on the accuracy of financial data and legislative stability. However, financial markets cannot be developed if there is no stability on politic, social, and economic arena.

Developed economies use financial markets to raise its economic level, to keep in equilibrium and the balance of payments, and to maintain economic and social stability. Under developing or emergent economies have consistently turned to financial markets to finance its balance of payments, or to accelerate the development of productive capacity, and for raising and maintaining social stability level.

For emerging economies, the establishment and development of financial markets involved or involves a process of reform of the financial system, adapting to the demands of investors, adopting new standards on the extent of powers of internal and in line with the requirements of integration in a regional context or wider international, insurance and maintain economic, and financial stability.

As a conclusion, financial markets really facilitate the development of countries, by putting together investors, individuals, and governments which have money or which are in need. Thus, financial markets participate actively in building and developing a sustainable economy.

\section{References}

Andrei Rădulescu, Senior Economist at Transilvania Bank, Moldova Republic. http:/capital.market.md/ro/content/andrei-radulescu-dezvoltarea-pietei-de-capital-poate-dinamiza-economia-moldovei Eugene, F., Brigham, Joel, F., Houston. (2016). Fundamental of Financial Management, South-Western College Pub. Jeff Madura. (2016). International Financial Management (13th ed.). Thomson South Western, USA.

https://en.wikipedia.org/wiki/Philadelphia_Stock_Exchange

https://www.ecb.europa.eu/press/key/date/2000/html/sp000912_2.en.html

http://www.investopedia.com/walkthrough/corporate-finance/1/financial-markets.aspx

https://www.ecb.europa.eu/press/key/date/2016/html/sp160322.en.html

https://www.ecb.europa.eu/press/key/date/2016/html/sp160204_1.en.html

http://writing.colostate.edu/guides/guide.cfm?guideid $=83$

http://reports.weforum.org/global-competitiveness-report-2015-2016/financial-market-efficiency/

http://www.frbsf.org/education/publications/doctor-econ/2005/january/financial-markets-economic-performance

https://www.bostonfed.org/news/speeches/rosengren/2008/100908.htm

http://www.economicshelp.org/blog/221/stock-market/how-does-the-stock-market-effect-the-economy-2/

http://www.brookings.edu/ /media/research/files/papers/2013/07/11-finance-role-in-economy-baily-elliott/11-finance-role-in-eco nomy-baily-elliott.pdf

https://www.stlouisfed.org/ /media/Files/PDFs/publications/pub_assets/pdf/re/2013/c/financial_markets.pdf

http://www.economist.com/blogs/buttonwood/2015/06/financial-markets-and-economy 